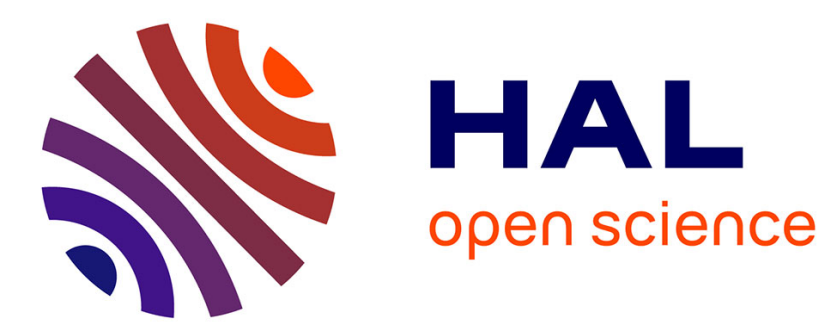

\title{
A tale of two destinies: Georgescu-Roegen on Gossen.
}

Paola Tubaro

\section{To cite this version:}

Paola Tubaro. A tale of two destinies: Georgescu-Roegen on Gossen.. History of Political Economy, 2014, 46 (1), pp.33-54. 10.1215/00182702-2398921 . hal-01354924

\section{HAL Id: hal-01354924 https://hal.science/hal-01354924}

Submitted on 20 Aug 2016

HAL is a multi-disciplinary open access archive for the deposit and dissemination of scientific research documents, whether they are published or not. The documents may come from teaching and research institutions in France or abroad, or from public or private research centers.
L'archive ouverte pluridisciplinaire HAL, est destinée au dépôt et à la diffusion de documents scientifiques de niveau recherche, publiés ou non, émanant des établissements d'enseignement et de recherche français ou étrangers, des laboratoires publics ou privés. 


\title{
A tale of two destinies: Georgescu-Roegen on Gossen
}

\author{
Paola Tubaro
}

\begin{abstract}
Nicholas Georgescu-Roegen edited the English translation of Gossen's book The Laws of Human Relations (1983), and wrote a lengthy introduction to it. His highly appreciative, thoroughly documented study has become a major reference on an otherwise little known early writer. It suggests that Gossen was unjustly ignored by his contemporaries, just as Georgescu-Roegen felt that his own contributions to economics were insufficiently recognized.

Yet it was not only a personal motive that inspired Georgescu-Roegen's editorial enterprise: I show that his original plan was to build a model of consumer choice, with support of hints found in Gossen, to address what he saw as essential theoretical issues. Rather, completion of the book project took almost twenty years, during which external circumstances and analytical difficulties gradually eroded the initial theoretical interests, while a sense of selfidentification with Gossen gained prominence. As a result, major issues remained ultimately unsolved. History of economics, originally intended to aid economic theory-building, became the key for sublimating personal feelings into a broader reflection on science in society, beyond time and space differences.
\end{abstract}




\section{Keywords}

Nicholas Georgescu-Roegen, Hermann Heinrich Gossen, utility theory, consumer choice theory, time allocation, time use, sociology of scientific discovery.

\section{JEL Codes}

A14, B21, D11

\section{Acknowledgements}

I acknowledge financial support from Gould Foundation with American Foundation for Paris School of Economics (Gould Fellowship), and from the Center for the History of Political Economy at Duke University. I thank librarians at the David M. Rubenstein Rare Book \& Manuscript Library at Duke University for their kind help and assistance in exploring the Nicholas Georgescu-Roegen archives, and I am grateful to Roxana Bobulescu, Robert Bolick, Yann Giraud, Clément Levallois, Samuel Iglesias, Andrea Maneschi, Kozo Mayumi, Jan van Daal, Fred Westfield and Stefano Zamagni for sharing valuable information with me. I thank Kevin Hoover and two anonymous referees of HOPE for their constructive suggestions, with which I have been able to make substantial improvements. Earlier versions also benefited from comments of participants in the lunch seminar of the Center for the History of Political Economy, Duke University, 3 April 2009, and the $12^{\text {th }}$ Summer Institute for the History of Economic Thought, University of Richmond, 26 June 2011. The usual disclaimer applies. 


\section{Author's biographical information}

I am senior lecturer (senior assistant professor) in economic sociology at the Business School of the University of Greenwich, London, UK, and research associate at Centre National de la Recherche Scientifique, Paris, France. I received my PhD in economics with a joint award from the University of Paris Ouest, France, and the University J.W. Goethe of Frankfurt, Germany. My research interests include the methodology of economics and the social sciences, as well as the history of economics. Among my recent publications in this area: "Computational economics", in The Elgar Companion to Recent Economic Methodology, J. B. Davis and D. W. Hands (eds.), 2011, Edward Elgar, 209-227; "Becker random behavior and the as-if defense of rational choice theory in demand analysis" (with I. Moscati), Journal of Economic Methodology, 2011, 18(2): 107-128; "History of Economic Thought", in 21st Century Economics: A Reference Handbook, R.C. Free (ed.), 2010, Sage Publications, Vol. 1: 3-11; “Is individual rationality essential to market price formation? The contribution of Zero-Intelligence Agent trading models", Journal of Economic Methodology, 2009, 16 (1): 1-19.

Contact information: Paola Tubaro, University of Greenwich, Business School, Old Royal Naval College, Room QA359, Park Row - Greenwich, London SE10 9LS, UK. Phone: +44 (0)20 8331 9625, email: P.Tubaro@greenwich.ac.uk. 


\section{Introduction}

Nicholas Georgescu-Roegen (1906-1994) is mostly remembered today for his work on bioeconomics and its implications on natural resources management, sustainability, and growth. In the first decades of his career, he had also extensively investigated utility theory and consumer choice on the one hand, and production theory on the other, contributing substantially to both areas (see for a synthesis Maneschi and Zamagni 1997). His hope to receive, and belief that he fully deserved, the Nobel Prize - which he never did - was one that he widely voiced among colleagues at Vanderbilt University, especially towards the end of his career. And it was precisely in this period that he made a major contribution to history of economics, with the English edition of Hermann Heinrich Gossen's book The Laws of Human Relations and the Rules of Human Action Derived Therefrom (1983).

Georgescu-Roegen's lengthy, thoroughly documented introductory essay to Gossen's book has become a key reference on an otherwise obscure older writer. Gossen, customarily classified among early marginalist authors, was a German civil servant with hardly any ties to academic institutions. His book, written in isolation in over twenty years and published at his expense in 1854, failed to attract any attention and, despite some posthumous praise (most notably by William S. Jevons and Léon Walras), it has remained relatively little known.

Georgescu-Roegen's essay conveys a distinctive sense of empathy between the author and his object of study. The reader can hardly escape the feeling that Gossen was unjustly ignored by his contemporaries, just as Georgescu-Roegen himself felt that his own contribution to economics was insufficiently recognized. His aspiration to win the Nobel Prize even appears 
between the lines -it was not much through historical work per se that he was trying to attract attention towards his credentials, but in a much subtler way.

But Georgescu-Roegen's venture into history of economics is not only a story of personal feelings, let alone vanity. It was Gossen's approach to consumer theory and utility that had triggered his enthusiasm in the first place. In previous writings, Georgescu-Roegen had sketched a novel approach to better incorporate time (and with it, the effects of experience and learning) into consumer models. Gossen's own emphasis on time, human experience, and the finiteness of time as the fundamental source of economic scarcity, resonated with his own views. Georgescu-Roegen realized that some of Gossen's ideas on time had gone almost unnoticed before, and had potential for further exploitation. The book project was, in fact, part of his broader theoretical and analytical effort to renew the economics of consumer choice and utility.

In this article, I set out to reconstitute the unfolding of Georgescu-Roegen's project to advance his own ideas with support of hints found in Gossen, the obstacles he encountered, and the changes in perspective, approach and focus he was led to make. To the best of my knowledge, there are no previous, systematic historical studies of this important episode in Georgescu-Roegen's intellectual career.

I show that completion of Georgescu-Roegen's editorial undertaking took almost twenty years and was highly convoluted - sharing a similar, unfortunate destiny with its own object, Gossen's original book. During this time, Georgescu-Roegen's outlook progressively changed: initially strong theoretical interests for consumer choice models eventually faded away, owing to his particular circumstances as well as to logical difficulties that emerged as analysis progressed. Meanwhile, the motive of self-identification with Gossen gradually gained 
prominence. Still, Georgescu-Roegen never kept it confined to the personal sphere, and rather brought forth a universal perspective: he transcended his own affinities with Gossen to develop a far-reaching reflection on the place of knowledge and discovery in societies, past and present. His use of historical research to illuminate similarities between individual destinies across time and space became a means to reveal and comprehend social regularities more generally.

What, then, of the initially intended role of history of thought -that of supporting economic model-building? Undoubtedly, Georgescu-Roegen derived substantial insight from his increasingly intimate knowledge of Gossen's book. He decidedly rejected the neoclassical consumer models and their graphical representations in modern textbooks in favor of Gossen's, which took account of the effects of the passage of time on consumer preferences and behaviors. Unfortunately, he was unable to go much beyond Gossen in attempting to formally incorporate time and its effects in consumer theory - which is one of the reasons why his attention eventually shifted to the entirely different issue of scientific discovery in society.

\section{The Gossen publication project: a dramatic story}

The published work - as can be consulted today - is a masterly example of the editing of economics texts and more generally, of history of economics scholarship. It is a joint enterprise of Georgescu-Roegen and his colleague Rudolph C. Blitz, who was also at Vanderbilt and was a native speaker of German. Blitz always acknowledged (in private correspondence as well as in his foreword to the book) that it was Georgescu-Roegen who first had the idea of working at the book and proposed it to him. The division of labor was almost naturally imposed by the distinct linguistic and theoretical skills of the two authors: Blitz would translate into English, and based on his work Georgescu-Roegen, who had limited command of German, would write an 
extensive introductory essay. In practice, Georgescu-Roegen also assisted his colleague with the translation, which necessitated major editorial interventions, not least because the original German text had no division into chapters, and no numbering of figures, tables, theorems and equations. The result is a text that is heavily edited, but significantly improved and much more easily readable than the original. In turn, Blitz supported Georgescu-Roegen's writing of the essay by providing not only the English text itself, but also translated summaries of existing German-language secondary literature on Gossen as well as substantial effort to search for additional historical and biographical sources. The book, including both the translation and Georgescu-Roegen's essay, was published in 1983 by MIT Press.

In fact, this final product is the outcome of a long and tortuous process unfolding behind the scenes. In what follows, I reconstitute the sequence of events that ultimately led to publication, and identify reasons that explain its duration.

The origins of the project can be traced as far back as 1965. The idea to publish an English version of Gossen's book, preceded by a lengthy introductory essay, was first discussed at the AEA annual meeting ${ }^{1}$, which took place at the end of December of that year in New York City. Georgescu-Roegen and Blitz met with Bert Hoselitz, who had translated Menger into English a few years before and was in the AEA translations committee at the time, and (following Hoselitz's own advice) with the publisher Augustus M. Kelley. Following up those conversations, Blitz rapidly secured a publication contract with Kelley ${ }^{2}$, and obtained funding both from the AEA (through Hoselitz) and from Vanderbilt University ${ }^{3}$. The two colleagues were initially highly optimistic about the time and effort required to complete the project and expressed hope "that the book will be published before September $1967^{\prime 4}$. Blitz promised Kelley "to put a draft into 
your hands at the latest by March 1967. [...] Professor Georgescu has assured me that he too would be able to complete his part of the manuscript by March" ${ }^{5}$. A first draft of Blitz's translation was indeed ready by the summer 1966, even though Blitz himself admitted it needed improvement ${ }^{6}$.

Difficulties started to emerge in the next few years. In the fall 1970, Blitz had to reassure Hoselitz that the project was still going on and he hoped to complete it shortly: "I appreciate your concern about the translation of Gossen. I am now within 15 pages of completing my fourth revision of the text" ${ }^{\prime 7}$. Yet Kelley did not receive any draft until the summer of $1971^{8}$, and Georgescu-Roegen had not even started writing his essay by this time. Nevertheless, Kelley was still interested and optimistic, and commented extensively on the draft translation when he finally received it $^{9}$.

The first draft of Georgescu-Roegen's essay saw the light only after Friedrich von Hayek provided a major unpublished source -a dissertation defended in Germany in 1931 whose author, Karl Robert Blum, used materials from archives of the public administrations where Gossen passed his professional qualification examinations and subsequently worked ${ }^{10}$. A very preliminary version of Georgescu-Roegen's draft, with the date of June 1973, includes only a two-page introduction together with historical and biographical sections. A revision in September of the same year also adds a literature review and some theoretical sections. Two further drafts (the former with the date of 1976; the latter undated but very similar to the former, and probably immediately posterior), refine the theoretical analysis; yet comparison with the final, published version reveals that they are still rather different from it, and largely incomplete. 
At about this time, an external event posed the single most serious threat to completion of the project: "we have recently been confronted with the imprevisible-Mr. Kelley sold out the firm. The new owner wants to direct its activity in other directions and we thought that, gentlemen as Rudy and I are, we better renounce the contract" ${ }^{11}$. Attempts by the two authors to find another publisher in 1976-77 ("Are you interested in the book?"12) did not yield any immediate results.

A positive turn came only in 1981, when MIT Press expressed an interest in publishing the book, seemingly through the decisive intermediation of Paul Samuelson ${ }^{13}$, a long-term friend of Georgescu-Roegen and a sincere admirer of his work, who had earlier on praised him as "a pioneer in mathematical economics" and "a scholar's scholar, an economist's economist" (foreword to Georgescu-Roegen 1966, vii). At MIT Press, "the only controversy about publishing the translation of Gossen's work was that it would be financially burdensome for it to undertake"14; yet funding from the National Endowment for the Humanities eventually made the project worthwhile ${ }^{15}$. The problem was rather that Georgescu-Roegen's essay had not significantly progressed since the second version of 1976, and it was this one that was submitted to the MIT Press editorial team for a first review ${ }^{16}$ ("the draft consists rather of an assembly of ideas classified in a rather rough way into provisional chapters" ${ }^{17}$ ). MIT Press apparently put some pressure on him to finalize the work quickly -much to the discontent of Georgescu-Roegen who often disagreed with editors' stylistic suggestions and experienced some difficulties in meeting his deadlines, partly because he no longer had secretarial assistance after his retirement ${ }^{18}$. In 1982, when the project was finally close to completion, MIT Press consulted Hayek to assess the project's worthiness, possibly following a suggestion of 
Georgescu-Roegen himself ${ }^{19}$. Hayek, who had himself written an introduction to a German edition of Gossen's book fifty years earlier, congratulated Georgescu-Roegen for the quality of his work in a letter in which he confessed being "a little ashamed" for not having done an equally valuable job: "Wholly inexperienced in the job of editing as I then was (at 27 years of age) I did my best to collect all available information, but did not even have time to re-read the book whose importance I had recognized but which I had never really closely studied"20.

There is little doubt that this long interval was largely determined by practical obstacles. Blitz occasionally lamented his colleague's lack of constancy and engagement in a project that he had himself launched ${ }^{21}$, but the linguistic barrier and Georgescu-Roegen's dependence on Blitz's translation account for his delay to a large extent. Blitz himself found the translation much more challenging and time-consuming than he initially expected ("the task of the translation turned out to be much more difficult than we originally anticipated"22). Furthermore, their search for historical and biographical sources on Gossen, on whom little was known before, yielded limited results: only the dissertation provided by Hayek, some secondary literature mostly in German, Hayek's own preface, and an Italian translation by Tullio Bagiotti (1950). The two authors tried in vain to trace Walras's French translation of Gossen, of which they had been informed by William Jaffé23 ${ }^{23}$ Georgescu-Roegen contacted the family of Georges Luftfalla who had been in possession of the manuscript, and was aware that it may have ended up in Luigi Einaudi's collection, but did not manage to find more precise information ${ }^{24}$. Blitz had unsuccessfully tried to locate the grave of Gossen in Germany during a stay there in $1975-76^{25}$, and even to search for potential descendants -in particular a "Gossen" firm in Erlangen, first mentioned to him by Hayek but probably unrelated ${ }^{26}$. The loss of the contract with Kelley, busy 
schedules and competing writing commitments - notably with Georgescu-Roegen's research on bioeconomics, very active throughout the 1970s - add to the impediments.

\section{Georgescu-Roegen's evolving view of Gossen}

During this long period, did Georgescu-Roegen's attitudes towards Gossen and his expectations for the editorial project change? I now discuss the emergence of a sense of commonality of destinies between Georgescu-Roegen and his object of study, and I show that it becomes detectable only at a relatively late stage in the history of the project. I subsequently provide evidence that Georgescu-Roegen's initial motivation was theoretical and focused on the renewal of consumer theory; this interest was strongest at the very beginning, though, and lost intensity over time.

\subsection{The late emergence of a sense of shared destinies}

The published version of the introductory essay opens with an "exordium" of about twenty pages entitled "Are there minds that may think above their time?" In a nutshell, the argument is as follows. In his History of Economic Analysis, Schumpeter judged that some economists including Gossen "wrote above their times"; so did Böhm-Bawerk (Georgescu-Roegen 1983, xii). Yet this very possibility is "in direct contradiction to [...] the 'sociology of knowledge"" of Robert K. Merton and others (Georgescu-Roegen 1983, xii). Georgescu-Roegen did not conceal his criticisms of what he saw as the main tenet of this discipline, namely "the inevitability of any 
discovery when the existentialist basis is just ripe for it" (Georgescu-Roegen 1983, xii) or more sarcastically, the idea that "Hamlet would have had to be written by someone else had Shakespeare not existed" (Georgescu-Roegen 1983, xiii). Admittedly, Georgescu-Roegen criticized this tenet in its strongest form and gave little consideration to any nuances that sociologists of knowledge may have introduced, but an appraisal of the accuracy of his argument would be beyond the scope of this article. Here, it is rather important to stress his claim that multiple discoveries are no more likely to be observed than "singletons". Discovery is so complex that what seems at first sight to be similar may in fact not be so. Take the JevonsMenger-Walras triad, typically credited to have brought about the so-called marginalist revolution: a closer look at their respective works reveals that they are very dissimilar, and "it was only much later that their contributions were consolidated into the general law as we know it today" (Georgescu-Roegen 1983, xvii). As a matter of fact, he insisted, we are much more likely to observe singletons: "any discovery, small or great, must, by definition, be in some sense above its time" (Georgescu-Roegen 1983, xviii). Precisely for this reason, it is all the more likely to face hostility, incomprehension, or oblivion - as was the case with Gossen.

Interestingly, this exordium was absent from the earlier drafts of 1973 and 1976, which all started with a much shorter introduction of about two pages: hence, it must have been added in 1982, just before publication. To be sure, the previous drafts also expressed regret for the neglect of Gossen, and reproached economists for failing to recognize his merits. Yet in the early stages of the project, Georgescu-Roegen's focus was on the peculiar fate of one particularly unlucky man. His switch to a wider sociological reflection and the reference to Merton in the final version of 1982 suggest instead that he was adopting a universal perspective: Gossen's 
destiny may not have been unique but rather the expression of a social regularity, revealing some deeper tendency in the way in which human communities organize the production and dissemination of knowledge. In this sense, his may be the destiny of all "minds above their times" -including Georgescu-Roegen himself. It was only at this late stage, then, that the personal motive of self-identification with Gossen gained relevance, visibility, and even scientific dignity as it was incorporated in a broader reflection on knowledge and society.

\subsection{Theoretical affinities fade away with time}

If Georgescu-Roegen's sense of self-identification with Gossen and its sociological legitimation appeared late, his initial interest in the book was entirely theoretically driven: he repeatedly and openly expressed his great admiration for Gossen's endeavor to build a consumer theory that could account for time and its effects on preferences and behaviors. A colorful detail helps introduce this point. In the preface to his book, Gossen had grandiloquently claimed that "I believe I have accomplished for the explanation of the relations among humans what a Copernicus was able to accomplish for the explanation of the relations of the heavenly bodies". Readers have invariably smiled at this pretension, but Georgescu-Roegen did not hesitate to point the finger at them in all his drafts of 1973 through 1976: "the claim is apt to offer the substance of a good joke, for Copernici in any field do not proclaim themselves as such. Yet in this case the joke should turn against those who may have joked about Gossen's claim. He is the Copernicus of economics" ${ }^{27}$. Surprising and by all measures extreme, this position is replaced with a more moderate one in the published version: "we have often smiled at Gossen and even 
ridiculed him, but, given the exceptional value of his contribution, the persiflage should turn against the ridiculers" (Georgescu-Roegen 1983, Ixv).

More generally, it was between the late 1960s and early 1970s that Georgescu-Roegen made use of his work on Gossen in his research. Figure 1 below provides a graphical sketch of the timeline. The lower panel represents his involvement in the book project, with start in 1965, drafts of the introductory essay in 1973 and 1976, and publication in 1983. The upper panel outlines occurrences of references to Gossen in other articles or essays of Georgescu-Roegen. The 1954 article is the first to mention Gossen, and does so only briefly; the 1985 one, published in an Italian journal, is a reprint of part of the introduction to the 1983 book. The articles written in the period 1968-73, instead, contain longer developments on Gossen, and GeorgescuRoegen's correspondence of this period clearly indicates that they benefited from the ongoing translation project, while in turn nourishing the theoretical reflection that informed the drafts of the introductory essay. To corroborate this point, consider also that most of GeorgescuRoegen's work on utility was done before the mid-1970s, and that all his subsequent research (apart from autobiographies and retrospective reflections) is in other areas. It is then unsurprising that the bulk of Georgescu-Roegen's theoretical work on Gossen was done in this time period, while only refinements and minor details were added later.

[INSERT FIGURE 1 ABOUT HERE] 


\section{Theoretical challenges: renewing consumer theory}

If Georgescu-Roegen had developed an interest in Gossen in the early phases of the editorial project, what was it that he found stimulating, and how did he expect to integrate suggestions from Gossen into his own research? To answer this question, I first review the work that Georgescu-Roegen had already done on utility theory; then I present Gossen's contribution, placing emphasis on the points that Georgescu-Roegen discussed most extensively; and finally, I assess the achievements and limitations of Georgescu-Roegen's endeavor on Gossen.

\subsection{Georgescu-Roegen's approach to consumer theory}

By the time he started working at the Gossen project, Georgescu-Roegen had written extensively on utility theory and made substantial contributions to the topic. A first, authoritative article was published in 1936 on the so-called integrability problem in demand theory. In sum, the question under scrutiny was whether it would be possible to recover indifference maps from the conditions of consumer equilibrium. A detailed account of Georgescu-Roegen's argument would be outside the reach of this article; the interested reader may wish to consult Zamagni (1999) and Hands (2006). It suffices here to briefly mention that Georgescu-Roegen demonstrated that there is no general solution to this problem unless preferences are transitive; however, the assumption of transitivity is unrealistic as it requires consumers to make comparisons over large changes in quantities of goods. This, said Georgescu-Roegen, is highly unlikely: humans have a "psychological threshold" of perceptions, including valuations of goods. They are not in a position to contemplate and consider the whole 
choice set but only minor variations among a smaller set of available bundles of goods -“local knowledge" in modern parlance. To take this limitation into account, he suggested a new approach, which he christened the theory of "directional choice" and in which indifference surfaces are not given but evolve endogenously over time depending on the consumer's past experiences of consumption. It is only by experimenting with different goods and combinations of them, that the consumer learns to refine his or her preferences, and adapts choice. This requires, however, a shift in emphasis relative to traditional theory, in which the consumer is supposedly aware of all consumption opportunities and makes the best choice out of them, so that any observed position in the choice space must be an equilibrium position. In directional choice theory, instead, the consumer can be initially in a disequilibrium position and can move from there, so that movements in the choice space are real movements in real time. Georgescu's analogy, comparing the two theories to the actions of, respectively, a bird and a worm, is illuminating: in conventional theory,

"choice is analogous to that of a bird which, after surveying from above a large piece of ground, dives directly at the most preferred spot. In the theory of directional choice, man's choice is rather like that of a worm which, from any position, chooses some direction and then moves along it" (Georgescu 1968a, 255).

Time must be placed at the heart of economic analysis as it is only over a period of time that the consumer can experiment with different goods and allow preferences to evolve.

Later on (1954), Georgescu-Roegen took up lexicographic preferences, plausible insofar as they represent the irreducibility of human needs. Traditional utility theory unifies all sorts of 
needs by pretending they are interchangeable, so that utility is the notion that summarizes all of them. Still, "he who does not have enough to eat cannot satisfy his hunger by wearing more shirts" (Georgescu-Roegen 1973a, 457). It is better, suggested the author, to move towards a conception that draws attention to a series of distinct wants, rather than just one (utility), following in this the original insight of early marginalist authors from Daniel Bernoulli to Carl Menger. Because human needs can be ranked on a scale going from the most basic ones (food, drink, shelter) to progressively more sophisticated ones, they will tend to be met in succession: therefore, consumption choices will follow paths in which basic needs are satisfied first, and other needs come sequentially. As a result, past choices will always affect current choices by determining the starting point, even when preferences themselves do not change. GeorgescuRoegen's defense of lexicographic preferences is another way to regard time as a major determinant of consumer choice, adding strength to the idea that there must be some form of hysteresis, an effect of the time arrow such that past actions are irreversible, at least to an extent. Since lexicographic preferences are not amenable to conventional representations of utility and in fact, are the textbook example of a case in which indifference curves are hardly meaningful, this point reinforces Georgescu-Roegen's mistrust towards conventional utility theory and its analytical tools.

In sum, Georgescu-Roegen's early work on utility and consumption had led him to believe that there was an unmet need for a better way to integrate time (and with it experience, evolving preferences and learning processes) into economic analysis. In his 1968 entry on "Utility" in the International Encyclopedia of the Social Sciences, he wrote: "There is little doubt that by far the greatest amount of work still to be done in utility theory concerns the time 
factor" (Georgescu-Roegen 1968a, 250). More generally, he had grown increasingly dissatisfied with the standard approach to utility, based as it was on the notion of indifference which he considered flawed: in this sense, he believed the shift from the older cardinalist to the newer ordinalist approach with Pareto and his followers had not brought as much improvement as was generally believed.

\subsection{Insight from Gossen?}

How, then, could Georgescu-Roegen avail himself of Gossen in support of his program to develop a theory of directional choice centered on time, experience, and irreversibility? To answer this question, it is first necessary to briefly present Gossen and his contribution, placing emphasis on those aspects that Georgescu-Roegen was most interested in.

The book starts with what commentators, from the late nineteenth century onwards, have taken the habit of calling "Gossen's First Law": a postulate, traditionally interpreted as roughly equivalent to the principle of decreasing marginal utility. Interestingly, however, Gossen stated it first in terms of time rather than quantities of goods: as an activity is pursued continuously over time, the enjoyment it yields decreases steadily until satiety is ultimately reached (Gossen 1983, 6). The more familiar version, in which marginal utility diminishes with the quantity of goods, is not a primitive principle in Gossen but is derived from the diminishing intensity of utility over time (Gossen 1983, 35). The latter can be regarded as more general (GeorgescuRoegen 1983, (xxx): it is because Gossen had first defined the psychological relation between utility and time, assumed to hold for any kind of enjoyable activity, that he could subsequently 
take into account that time is needed to consume commodities -a concern rarely found in modern economics.

The First Law can be represented graphically as a negatively-sloped schedule in a diagram in which time (or quantity of a good) is on the abscissa, and marginal utility on the ordinate (curve $c b$ in Figure $2 a$ ). Georgescu-Roegen who had long discussed the respective merits of ordinalist and cardinalist approaches in his earlier writings (see above) stresses that as originally formulated, Gossen's principles do not need any assumption of cardinality:

"the time represented on the horizontal axis [...] need not be clock-time; time as a pure flow ordered only by the subjective relation 'earlier than' will do. Nor need the feelings of pleasure at any moment in life be cardinally measurable; it suffices that these feelings be ordinally comparable" (Georgescu-Roegen 1983, Ixxx).

The $c b$ curve can be shifted upwards or downwards with no major consequences on the main result; and it is required only to be downward-sloping without any other restrictions on its shape (though for simplicity's sake, Gossen often assumed linearity). Georgescu-Roegen insisted on the originality of this formulation relative to other versions of the principle of decreasing marginal utility, which assumed cardinality along both the vertical and horizontal axes (1983, Ixxx). However, he admitted that the original text of Gossen is at times hesitant and even contradictory on these matters (Georgescu-Roegen 1983, Ixxxiv). In particular to compare the utility derived from different goods or enjoyable activities, Gossen reintroduced a form of measurability assuming that "any mathematical magnitude [...] consists of atoms and that the atoms can be separated one by one and rearranged at will" (Georgescu-Roegen 1983, Ixix). 
Gossen's atomism can be somewhat excused for ignoring the mathematical notion of continuity, not yet known in the mid-nineteenth century; but a more serious inconsistency "was his further assumption that one atom of, say, milk is equal to an atom of, say, coal" (1983, Ixix).

[INSERT FIGURE 2 ABOUT HERE]

Gossen also provided a simple, clever graphical solution to the question of how to allocate one's time in order to maximize total utility, when several activities are available but time is limited and does not allow reaching satiety for all of them. Again, this is easily generalized to the problem of the optimal allocation of a scarce factor among distinct uses; the fact that Gossen took time as his starting point gives unity to his whole thought, indicating that the origin of scarcity is time alone, and all other material shortages are just consequences of it (GeorgescuRoegen 1983, lxv). Gossen's optimal solution expresses the principle that the end intensities of pleasure in each use must be equal (Gossen 1983, 14). While the general principle is correct, Gossen's solution is unsatisfactory when it comes to actually comparing the pleasures resulting from qualitatively different enjoyments, as he simply assumed that atoms of any two goods are equal. Yet he "hit on the correct idea" (Georgescu-Roegen 1983, xciv) when, having introduced money and a price system, he drew the conclusion that the last unit of money spent in each enjoyment must provide the same intensity of pleasure. This proposition can be translated algebraically to state that the optimal allocation of income over different goods must be such that the ratio of marginal utility and price is the same for each good, a solution that has since 
then become standard in economics literature. The graphical device that Gossen propounded to illustrate this point (figure $2 b^{28}$ ) is also found in other authors, notably Jevons, Philip Wicksteed and Knut Wicksell; Georgescu-Roegen reproduced it both in his 1968 Utility entry in the Encyclopedia, and in an article in the Southern Economic Journal of the same year. He even referred to it in a letter to Paul Samuelson of 1974, to criticize a point in a draft paper by the latter ${ }^{29}$. Georgescu-Roegen summarized the reasons for his appreciation of the diagram, alluding to his own criticisms of the indifference notion:

“Gossen's diagrams are no longer found in the recent economic manuals because the problem of allocation is now explained with the help of the indifference map. Yet Gossen's diagram reaches deeper into the relationship between allocation and utility and is therefore the most efficacious tool for any argument that may safely assume the independence of utilities" (Georgescu-Roegen 1983, xci).

Gossen's solution had customarily been referred to in the literature as "Gossen's Second Law", a label that Georgescu-Roegen strongly criticized because of the confusion it induces: indeed the Second Law is a theorem, while the First Law is a postulate.

Ignoring traditional usage, Georgescu-Roegen applied the term Second Law to a different mechanism for diminishing utility (also a postulate): "If a previous enjoyment is repeated after an interruption, the intensity-of-pleasure schedule shifts, depending on the individual's previous experiences of enjoyment. The sooner the repetition, the larger the shift". With reference to figure $2 c^{30}$, this would mean that the intensity of pleasure would be represented by $c^{\prime} b^{\prime}$ instead of $c b$. In this perspective, Gossen suggested (but did not prove) that it may in principle be 
possible for an individual to identify the optimal frequency of repetition of activities, thereby maximizing enjoyment over one's lifetime. Gossen also suggested that there may be forms of learning, so that exercising the sensory organs helps the intensities of pleasure become greater.

Georgescu-Roegen considered this mechanism as Gossen's single most important innovation. The underlying idea that consumer choice "is intertwined with a continuous process of learning or, rather, of discovering one's own latent structure of pleasure" (Georgescu-Roegen 1983, Ixxxv) obviously resonated with his earlier plea for a theory in which utility (or preferences) change as a result of past experiences. This is the main reason why, in his early drafts, he had insisted on comparing Gossen to Copernicus:

"He is the Copernicus of economics. Like Copernicus, he was the man of one idea, only, as Edgeworth rightly judged [...], that idea was a genial one. One can even detect some immense pride in the direct and unreserved way in which Jevons recognized that Gossen had anticipated him. [...] The same applies to Walras. [...]. The whole truth, however, is that in at least one respect -namely, what I shall later on call Gossen's Second Law- he anticipated nobody, simply because that particular point has not been thought up by anyone else ${ }^{31}$."

Georgescu-Roegen's introduction incorrectly suggests that this principle is unique to Gossen among marginalist writers, and escaped notice by later commentators: "no one is known to have said anything even approaching it before him, or after him, for what matters" (1983, Ixxxiv). However, versions of this law can be found in other early neoclassical economists, most prominently Maffeo Pantaleoni who explicitly attributed it to Gossen (1898, 28-38), and 
Francis Y. Edgeworth $(1967,62)$. They interpreted it rather in terms of quantities of goods, meaning that the functional relationship between different quantities of a good and the amount of pleasure they yield in a given time period shifts according to individual previous experiences of consumption of that same good (Bruni and Sudgen 2007). Hands (2008) adds that traces of this principle can be found in consumer theory even later, until about the 1930 s.

Be that as it may, Georgescu-Roegen's account of the reasons why the Second Law was disregarded is of interest in itself. His 1973-76 drafts suggest that this was just part of the neglect of which Gossen had been a (particularly unfortunate) victim; the published version, however, rather points to the formidable challenges that would arise if one tried to explore it mathematically ("its complexity does not allow the economic theorist to get much mileage from it", Georgescu-Roegen 1983, Ixxxv). He attempted to formalize and solve Gossen's problem of finding the frequency of repetition of enjoyments that would maximize utility over one's lifetime. However his argument, found both in the drafts and the published version, does not reach any universal solution, and suggests that the problem can be treated only in an ad hoc manner. He openly pointed to the need of renovating the set of mathematical and analytical tools available to economists, so as to make dynamic problems tractable:

"there is no way to represent this learning process by the ordinary tools of mathematics; the most we can do is to illustrate it by a simile [...]. But even if we abstract from this process, as has been done in the few attempts to study preferences among time sequences of utilities, one has to introduce simplifying assumptions of scarcely any degree of realism" (Georgescu-Roegen 1983, Ixxxvi). 


\subsection{Mixed results}

To summarize, Georgescu-Roegen believed that Gossen's thought centered on time purported a potentially fruitful approach to the question of how utility could change with time, and provided a framework of analysis which, though somewhat primitive, was exempt from the flaws of the ordinalist, indifference-curve based, approach. Gossen's book offered a background for his claim that it was essential to rebuild the foundations of consumer choice theory so as to fully include time and its consequences -experience, learning, and irreversibility. In particular, Georgescu-Roegen saw potential for the Second Law to be developed further, and his effort to prove the general theorem of lifetime enjoyment optimization can be seen as a first step in this direction.

However as already mentioned, Georgescu-Roegen reached no general solution to the problem of optimizing time use over one's lifespan. As mentioned above, a major difficulty was the lack of mathematical and analytical tools that are adequate enough to model dynamic phenomena. Georgescu-Roegen was famously aware of the limitations of mathematics, an issue that he repeatedly raised in the last decades of his life; but he did not go as far as to experiment with alternative tools and remained a traditionalist, so to speak, in terms of methods.

What's more, Gossen's approach did not offer sufficient help to build a convincing case for support of an alternative consumer theory, with respect to the existing approach based on indifference curves. For all its novelty and interest, it was not exempt from all the problems of early marginalism. The aforementioned atomism is a first example of these difficulties; another 
is the imperfect correspondence between total and marginal utility, which Georgescu-Roegen discussed at length: if it is mathematically straightforward to see that the curve $c b$ corresponds to the marginal concept and the surface below it to the total concept, a substantive interpretation would require some mechanism for "accumulating" utility, so that the notion of total utility would correspond to a real psychological experience. In a sense, then, most of the problems that were open in 1965, when the book project started, were still largely unsolved in 1983, when it finished.

\section{Conclusions}

Like Gossen whom he much admired, Georgescu-Roegen was at the forefront of the development of consumer theory. He spotted essential problems as early as 1936, when the standard utility maximization model was still in the process of being built, and many of its pillars as they are found in today's textbooks, had yet to see the light. With his theory of directional choice, he identified a path to be explored for further analytical progress, and raised important challenges. His emphasis on time and its effects on preferences and choices was the unifying principle of his view of how consumer theory should be rebuilt, and his work on Gossen was part of this endeavor.

However during his lifetime, Georgescu-Roegen failed to convince the profession of the need for profound theoretical change that he had advocated. To be sure, some economists did take up the indications of his theory of directional choice, developing them towards various theoretical objectives (see for a brief review Zamagni 1999, 105); yet a larger majority remained 
faithful to the mainstream approach. At times, Georgescu-Roegen regretted this explicitly: for example, when in an important book on preferences, utility, and demand, edited by John Chipman and allegedly representing "the most up-to-date statement" of consumer theory, "highly important topics such as [...] the time factor [...] have been completely left out" (Georgescu-Roegen 1973b, 529). One reason for the reserved reception of Georgescu-Roegen's ideas is that his starting point, the integrability problem in demand theory, had been dismissed by many as little relevant: Hicks $(1939,19)$ considered it a "will-o'-the-wisp", and so did Houthakker and others (Zamagni 1999, 110-111; Hands 2006). Another reason is his growingly confrontational stance towards other economists which, especially in the last decades of his life, hindered successful communication and penetration of his views (Iglesias 2009).

The Gossen editorial project hardly contributed to reviving awareness of GeorgescuRoegen's approach to utility theory. Its long duration and the numerous practical difficulties encountered throughout the process, together with his growing focus on the new area of bioeconomics, distracted attention from the theoretical issues that had brought him to study Gossen in the first place. By the mid-seventies, it was no longer obvious to all that utility theory, "the topic that has been my liebling thema" ${ }^{32}$, was one of his major theoretical interests, and he often felt the need to specify it explicitly ("My first field was utility theory" ${ }^{33}$ ).

When the book finally came out, it was well-received: Laurence Moss wrote a positive review ("Collaborators Blitz and Georgescu-Roegen along with the editors deserve our gratitude and praise for this handsome and authoritative volume", 1984, 1132), and there was a session on "New perspectives on H.H. Gossen, The Laws of Human Relations (1854)" at the 1984 AEA meetings in Dallas. However, little else happened. The book is now out of print and even used 
copies are unavailable for purchase, either from the publisher or from major online retailers. Google Scholar reports only 68 citations $^{34}$, a tiny number compared to more than 3000 for Georgescu-Roegen's 1971 book on The Entropy Law and the Economic Process, and more than 400 for his 1966 Analytical Economics.

As a result, the book is less remembered today for its contribution to utility theory, than for Georgescu-Roegen's thoughts on discovery and the place of outliers in the sociology of knowledge, with the related plea for systematic recognition of scientific merit as an essential ethical and professional requirement. It should not be inferred, though, that GeorgescuRoegen's exercise in history of economics was of little use: rather, it was on the basis of it that he could generalize his argument on the place of science in society. His effort unveils a potentially large range of possible uses of history of economics - not necessarily successful in contributing to economic theory-building but feeding into more diverse avenues of inquiry, possibly involving neighboring disciplines and their relationships with economics. 


\section{References}

Bruni, L. and R. Sudgen. 2007. The road not taken: How psychology was removed from economics, and how it might be brought back. The Economic Journal 117: 146-173.

Edgeworth, F. Y. 1967 [1881]. Mathematical Psychics. New York: Kelley.

Georgescu-Roegen, N. 1936. The pure theory of consumer's behavior. Quarterly Journal of Economics 50: 545-593.

---- 1950. The theory of choice and the constancy of economic laws. Quarterly Journal of Economics 64: 125-138.

---- 1952. A diagrammatic analysis of complementarity. Southern Economic Journal 19: 1-20.

---- 1954a. Choice, expectations and measurability. Quarterly Journal of Economics 68: 503-534.

---- 1954b. Choice and revealed preference. Southern Economic Journal 21: 119-30.

---- 1958. Threshold in choice and the theory of demand. Econometrica 26: 157-168.

---- 1966. Analytical Economics. Cambridge, MA: Harvard University Press.

---- 1968a. Utility. In The International Encyclopaedia of the Social Sciences, Vol. XVI, New York: Macmillan, 236-267. 
---- 1968b. Revisiting Marshall's constancy of marginal utility of money. Southern Economic Journal 35: 176-181.

---- 1969. The relation between binary and multiple choices: Some comments and further results. Econometrica 37: 728-730.

---- 1971. The Entropy Law and the Economic Process. Cambridge, Mass.: Harvard University Press.

---- 1973a. Utility and value in economic thought. In Dictionary of the History of Ideas, New York: Scribner's, Vol. IV, 450-458.

----1973b. Review of Preferences, Utility, and Demand. A Minnesota Symposium, by John S. Chipman et al. Journal of Economic Literature 11 (2): 528-532.

---- 1983. Hermann Heinrich Gossen: His life and work in historical perspective. In H. H. Gossen, The Laws of Human Relations and the Rules of Human Action Derived Therefrom, xi-cxlv. Cambridge (MA) and London: MIT Press.

Gossen, H. H. 1983 [1854]. The Laws of Human Relations and the Rules of Human Action Derived Therefrom, English translation by R. C. Blitz, with an introductory essay by N. GeorgescuRoegen. Cambridge (MA) and London: MIT Press.

---- 1995 [1854]. Exposition des lois des relations humaines, French translation by L. Walras and C. Secretan, edited by J.M. Servet, J. van Daal, A. Jolink and J.P. Potier, Paris : Economica. 
Hands, D. W. 2008. The road may not have been taken, but it was explored: Behavioral economic concerns in early twentieth century consumer choice theory. Working paper. 21

---- 2006. Integrability, rationalizability, and path-dependency in the history of demand theory. In Agreement on Demand: Consumer Theory in the Twentieth Century, edited by D.W. Hands and P. Mirowski, annual Supplement to History of Political Economy 38: 153-185.

Hicks, J. R. 1939. Value and Capital. Oxford: Oxford University Press.

Iglesias, S. L. 2009. The Miscommunications and Misunderstandings of Nicholas GeorgescuRoegen. Honors Thesis, Duke University.

Maneschi, A. and S. Zamagni. 1997. Nicholas Georgescu-Roegen, 1906-1994. The Economic Journal 107: 695-707.

Moss, L. 1984. Review of The Laws of Human Relations and the Rules of Human Action Derived Therefrom, by Hermann Heinrich Gossen; Rudolph C. Blitz; Nicholas Georgescu-Roegen. The Journal of Economic History 44 (4): 1130-1132.

Pantaleoni, M. 1898 [1889]. Pure Economics. London: Macmillan. English translation of the Italian edition (Florence: Barbera).

Samuelson, P. A. 1974. Complementarity: An essay on the 40th anniversary of the Hicks-Allen revolution in demand theory. Journal of Economic Literature 12: 1255-1289. 
Zamagni, S. 1999. Georgescu-Roegen on consumer theory: an assessment. In K. Mayumi and J. Gowdy, Bioeconomics and Sustainability: Essays in Honor of Nicholas Georgescu-Roegen. Cheltenham: Edward Elgar, 103-24. 


\section{Figures}

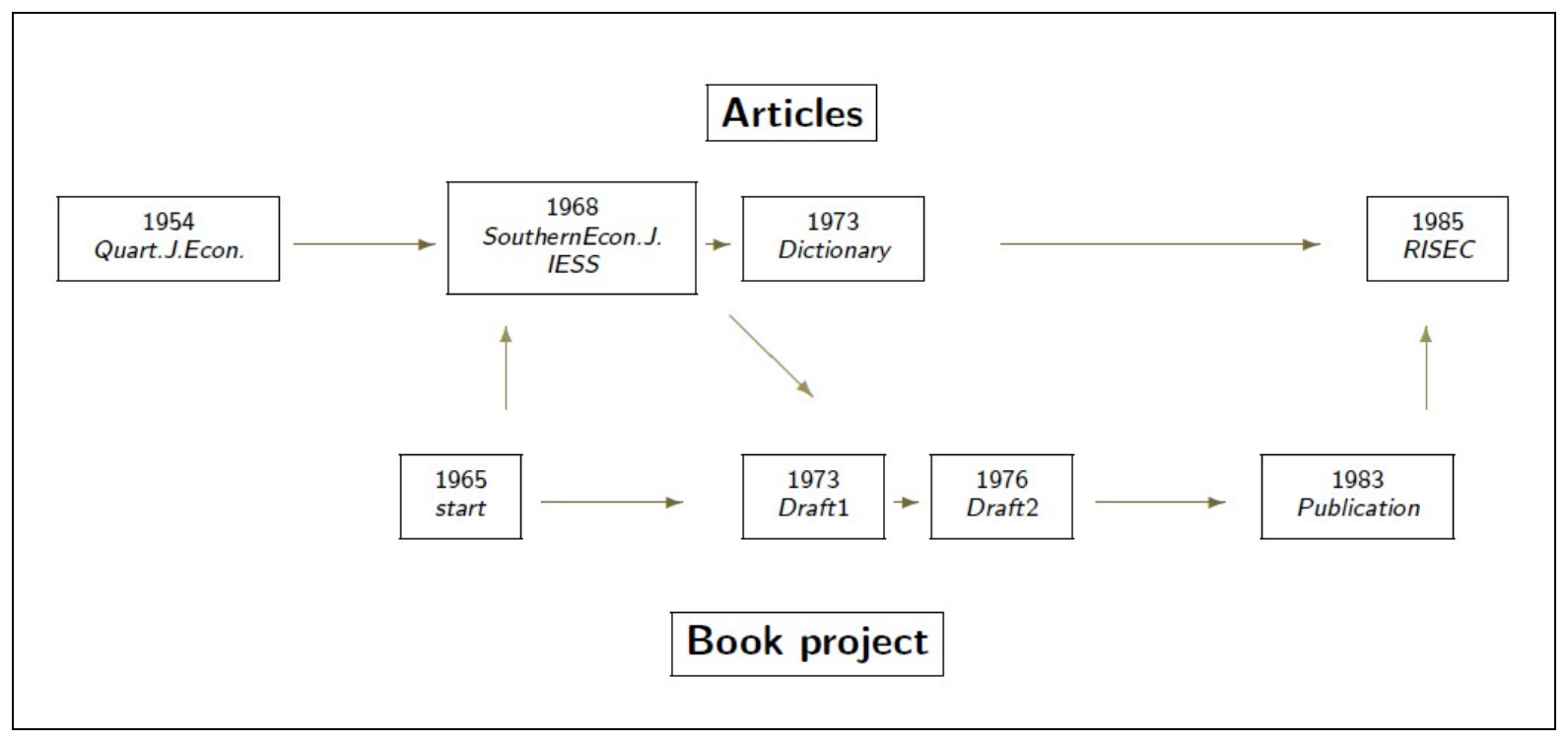

Figure 1: timeline of Georgescu's work on Gossen. 


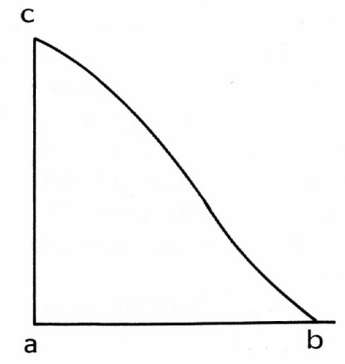

Figure 2a: First Law

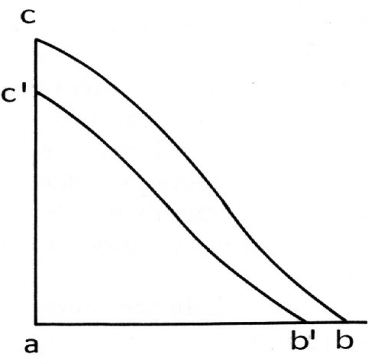

Figure 2c: Second Law

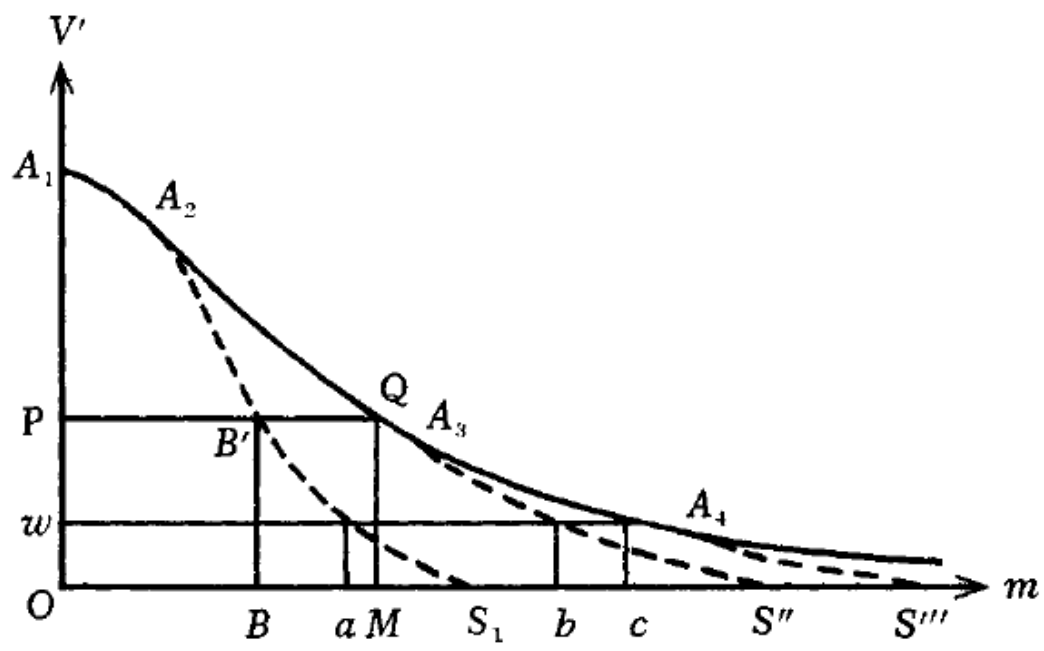

Figure $\mathbf{2 b}$ : optimality solution

Figure 2: Gossen's graphical approach. 
${ }^{1}$ Letter of Blitz to Kelley, 17 January 1966; Kelley to Blitz, 1 February 1966. All correspondence and manuscripts cited are (unless otherwise specified) at the David M. Rubenstein Rare Book \& Manuscript Library of Duke University, Economists' Papers Project, Nicholas Georgescu-Roegen papers, box n. 21.

${ }^{2}$ Letter of Kelley to Blitz, 23 March 1966, enclosing a draft contract proposal; Blitz to Kelley (cc to Georgescu-Roegen), 29 March 1966; Blitz to Kelley, enclosing a revised contract proposal, 8 April 1966.

${ }^{3}$ Letter of Blitz to Bert Hoselitz, 29 March 1966; Hoselitz (on behalf of the AEA) to Blitz, detailing the conditions of the award, 23 May 1966. The AEA provided a grant of $\$ 700$ of which, in line with Blitz’s request, “\$200 for a special reader and $\$ 500$ for retyping" (Hoselitz to Blitz, 23 May 1966), followed by another $\$ 300$ in the summer. The "special reader" was a linguist, Professor Heinrich Meyer of Vanderbilt's German Department. Vanderbilt University covered Blitz's summer salary and some secretarial assistance.

${ }^{4}$ Letter of Blitz to Hoselitz, 26 May 1966.

${ }^{5}$ Letter of Blitz to Kelley, 14 February 1966.

${ }^{6}$ Letter of Blitz to Georgescu, handwritten, 27 February 1969.

${ }^{7}$ Letter of Blitz to Hoselitz, 5 October 1970.

${ }^{8}$ Letter of Blitz to Kelley and Frederick S. Cheesman (of Augustus M. Kelley Publishers), 5 July 1971.

${ }^{9}$ Letter of Kelley to Blitz, 29 August 1972.

${ }^{10}$ Hayek, who had received a copy from Blum's advisor and deposited it at the library of the University of Salzburg, arranged for a photocopy to be mailed to Blitz (Letter of Blitz to Hayek, 25 September 1972; Hayek to Blitz, 19 October 1972; Blitz to Hayek, 30 October 1972; Hayek to Blitz, 3 November 1972).

${ }^{11}$ Letter of Georgescu-Roegen to Maurits Dekker (Chairman of the Board of the Marcel Dekker publishing house, New York), 3 March 1977.

12 Letter of Georgescu-Roegen to Dekker, 3 March 1977.

${ }^{13}$ I have had this information from Jan van Daal (personal conversation, September 2003), Yann Giraud (email, 1 June 2011) and Clément Levallois (email, 15 June 2011), who all had it from Laurence Moss. I did not find any confirmation (or disconfirmation) of it in archival materials.

${ }^{14}$ I have had this information from Robert Bolick, who was at the time Acquisitions Editor at MIT Press (email, 8 February 2012).

${ }^{15}$ Letter of Bolick to Georgescu-Roegen, cc to Blitz, 20 July 1981.

${ }^{16}$ The drafts submitted to, and edited by, MIT Press are in box 20 of the Georgescu-Roegen collection at Duke library.

${ }^{17}$ Letter of Georgescu-Roegen to Bolick, 4 September 1981. 
18 "This time again I found myself with a pressing demand to revise the text within an unreasonable time by any standard". Letter of Georgescu-Roegen to Robert Ross (Editor at MIT Press), cc to Blitz and Bolick, 10 August 1983. 19 "As I take it that it was at your suggestion the MIT Press sent me your introduction to the English translation of Gossen for an opinion..." Letter of Hayek to Georgescu-Roegen, 10 May 1982.

${ }^{20}$ Letter of Hayek to Georgescu-Roegen, 10 May 1982.

${ }^{21}$ Letter of Blitz to Georgescu, handwritten, 27 February 1969. Former colleagues at Vanderbilt University confirm that Blitz was uncomfortable with the timing of the project. I have had this information from Andrea Maneschi and Fred Westfield (email, 14 April 2009).

${ }^{22}$ Translator's foreword, in Gossen (1983).

${ }^{23}$ Letter of Blitz to Kelley, 17 January 1966.

${ }^{24}$ Letter of Georgescu-Roegen to Mme Georges Luftfalla, 31 October 1966; Michel Luftfalla (son of Georges) to Georgescu-Roegen, 4 November 1966. Walras's manuscript was found thirty years later among Einaudi's papers, and finally went to press (Gossen 1995).

${ }^{25}$ Letter of Blitz to Georgescu-Roegen, handwritten, 22 September 1975; Blitz to Georgescu-Roegen, handwritten, 25 March 1976.

${ }^{26}$ Letter of Blitz to Hayek, 24 June 1969; Hayek to Blitz, 1 July 1969; Hayek to Blitz, 18 February 1970.

${ }^{27}$ The same sentence is in the 1973 and in the 1976 manuscripts. Emphasis is Georgescu-Roegen's.

${ }^{28}$ Gossen's diagram can be read as follows. Time (monetary income) is measured on the horizontal axis; for every level on the vertical axis, one adds the corresponding abscissas of the curves representing the marginal utilities of different activities (sums of money spent on different goods, at given prices), obtaining the curve $A 1 A 2 S^{\prime \prime}$. On this diagram, one directly reads any optimal budget. For example, if total available time (income) is $O M$, then $O B$ should be used for activity (good) 1 and BM to for activity (good) 2. The graph is reproduced from Georgescu-Roegen (1968: 244).

${ }^{29}$ The draft was a study on complementarity, and would be published in December 1974. In an example, Samuelson had assumed that the marginal utility of a good (salt) was constant and concluded that one will spend one's entire income on salt. Georgescu-Roegen objected that "you may consume no salt at all. All depends on the relative prices. (For the case of independent commodities, the Gossen diagram clears the issue immediately. [...] You would spend always your entire income in salt only if its marginal utility were infinite." Letter of Georgescu-Roegen to Samuelson, handwritten, 31 August 1974. Emphasis is Georgescu-Roegen's. The idea that constant marginal utility of a good involves spending the whole of one's income in that good is absent from the published version of Samuelson's article. 
${ }^{30}$ Diagram $2 c$ is reproduced from Gossen (1983). Diagram $2 a$ is an adaptation from it, which I have chosen for greater clarity (though very similar graphs are also found in Gossen).

${ }^{31}$ Georgescu-Roegen, Essay, manuscript of 1973 (September), 1.

${ }^{32}$ Letter of Georgescu-Roegen to Dr Douglas Greenwald, editor in chief, McGraw-Hill Encyclopedia of Economics, 13 January 1992. Emphasis is the author's.

${ }^{33}$ Letter of Georgescu-Roegen to Dekker, 3 March 1977.

${ }^{34}$ Data were retrieved in February 2012 with keywords "Nicholas Georgescu-Roegen”, "Georgescu-Roegen Gossen”, "Gossen 1983"; the figure excludes unpublished papers, translations, reprints, and pre-1983 publications. 